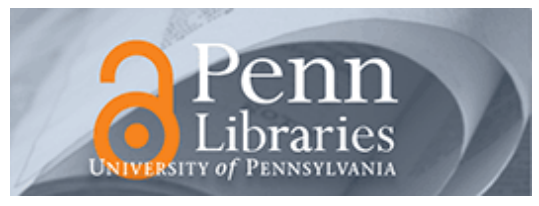

University of Pennsylvania

ScholarlyCommons

Management Papers

Wharton Faculty Research

$2-2003$

\title{
Moving to Greener Pastures? Multinationals and the Pollution Haven Hypothesis
}

Gunnar S. Eskeland

Ann E. Harrison

University of Pennsylvania

Follow this and additional works at: https://repository.upenn.edu/mgmt_papers

Part of the International Business Commons, and the Other Business Commons

\section{Recommended Citation}

Eskeland, G. S., \& Harrison, A. E. (2003). Moving to Greener Pastures? Multinationals and the Pollution Haven Hypothesis. Journal of Development Economics, 70 (1), 1-23. http://dx.doi.org/10.1016/ S0304-3878(02)00084-6

This paper is posted at ScholarlyCommons. https://repository.upenn.edu/mgmt_papers/158

For more information, please contact repository@pobox.upenn.edu. 


\title{
Moving to Greener Pastures? Multinationals and the Pollution Haven Hypothesis
}

\author{
Abstract \\ robust across specifications.

\section{Keywords} \\ foreign investment, pollution haven, environment, multinational \\ Disciplines \\ International Business | Other Business
}

This paper presents evidence on whether multinationals are flocking to developing country "pollution havens". Although we find some evidence that foreign investors locate in sectors with high levels of air pollution, the evidence is weak at best. We then examine whether foreign firms pollute less than their peers. We find that foreign plants are significantly more energy efficient and use cleaner types of energy. We conclude with an analysis of U.S. outbound investment. Although the pattern of U.S. foreign investment is skewed towards industries with high costs of pollution abatement, the results are not 


\title{
MOVING TO GREENER PASTURES? \\ MULTINATIONALS AND THE POLLUTION HAVEN HYPOTHESIS
}

\author{
Gunnar S. Eskeland \\ Ann E. Harrison \\ Working Paper 8888 \\ http://www.nber.org/papers/w8888 \\ NATIONAL BUREAU OF ECONOMIC RESEARCH \\ 1050 Massachusetts Avenue \\ Cambridge, MA 02138 \\ April 2002
}

\begin{abstract}
We would like to thank Ricardo Sanhueza for superb research assistance. We are greatly indebted to David Wheeler and Manjula Singh for helpful conversations, for making their database available, and for estimating the results based on U.S. data. We would also like to thank Art Small, Tarhan Feyzioglu, and two anonymous referees for very helpful comments. The views expressed herein are those of the authors and not necessarily those of the National Bureau of Economic Research or The World Bank.
\end{abstract}

(C) 2002 by Gunnar E. Eskeland and Ann E. Harrison. All rights reserved. Short sections of text, not to exceed two paragraphs, may be quoted without explicit permission provided that full credit, including $(\mathcal{C}$ notice, is given to the source. 
Moving to Greener Pastures? Multinationals and the Pollution Haven Hypothesis Gunnar E. Eskeland and Ann E. Harrison

NBER Working Paper No. 8888

April 2002

JEL No. F23, Q2

\begin{abstract}
This paper presents evidence on whether multinationals are flocking to developing country "pollution havens". Although we find some evidence that foreign investors locate in sectors with high levels of air pollution, the evidence is weak at best. We then examine whether foreign firms pollute less than their peers. We find that foreign plants are significantly more energy efficient and use cleaner types of energy. We conclude with an analysis of US outbound investment. Although the pattern of US foreign investment is skewed towards industries with high costs of pollution abatement, the results are not robust across specifications.
\end{abstract}

Gunnar A. Eskeland

The World Bank

1818 H St. NW

Washington, DC 20433

geskeland@worldbank.org
Ann E. Harrison

University of California

329 Giannini Hall

Berkeley, CA 94720

and NBER

510-643-9676

harrison@are.berkeley.edu 


\section{Introduction}

Passage of the North-American Free Trade Agreement (NAFTA) reawakened fears that multinationals would flock to Mexico to take advantage of lax environmental standards. This is the socalled pollution haven hypothesis, which states that environmental regulations will move polluting activities for tradeable products to poorer countries. Although existing studies suggest little or no evidence of industrial relocation, arguments over pollution havens persist. Why?

One answer lies in the fact that the existing literature is primarily based on anecdotes and scattered case studies. Even the best studies, such as Leonard (1988), make no effort to assess statistically the relationship between the distribution of US foreign investment and pollution intensity. Most of these studies make no attempt to control for other factors which may play a role in determining foreign investment, such as large protected markets. Many of the earlier studies (Pearson, 1985 and 1987; Walter, 1982) use evidence from the 1970s and early 1980s, when the flow of foreign investment to developing countries was not as high as it is today. One exception is the recent work by Grossman and Krueger (1993), which focuses on maquiladora activity in Mexico. Yet their research also serves to highlight the difficulty in explaining the pattern of US investment abroad. They show that neither pollution abatement costs nor other likely determinants can adequately explain the pattern of maquiladora activity in Mexico.

Although there is a growing literature on the determinants of global environmental quality, little research has been done to test the pollution haven hypothesis. ${ }^{2}$ In this paper, we begin by presenting a

\footnotetext{
2 Instead, much of the literature focuses on the relationship between income growth and pollution. Grossman and Krueger (1995) postulate an inverted 'u-curve'. This empirical relationship has found support in other studies as well (see Selden and Song, 1994; The World Bank, 1992). The hypothesis, supported by their empirical analysis, states that pollution will first increase with income, then decrease at higher income levels. The initial upward relationship occurs because of a positive relationship between output and emissions. The downward tendency occurs when higher demand for environmental quality at higher income levels forces the introduction of cleaner technologies (the technique effect) and an output combination which is less polluting (the composition effect).
}

A related literature examines the relationship between openness and environmental quality. Again, the links can be 
simple model which shows that the effect of environmental regulations imposed at home on outward investment is ambiguous. Depending on possible complementarities between capital and pollution abatement, environmental regulation could lead to an increase or a decline in investment in both the host (developing) country and the originating (developed) country. In other words, environmental regulation in the home country could lead a firm to increase or reduce its investment in both the home country and in the country where environmental standards are less stringent.

To resolve the theoretical ambiguity, we turn to an empirical analysis of the pattern of foreign investment. Our research focuses on three related issues. We begin by analyzing the pattern of foreign investment in a number of developing countries--looking for evidence which reflects increasing costs of pollution-intensive activities at home. To control for other factors which may be important in helping to attract foreign investment, we create measures of trade policies, industrial concentration, the domestic regulatory environment, factor endowments, and wages at home. We use data from four host countries: Cote d'Ivoire, Morocco, Mexico, and Venezuela.

Second, we compare the behavior of multinational firms in developing countries with their counterparts in the host country. In particular, we focus on the emissions behavior of foreign and domestic plants within the same manufacturing sector. Since emissions across a wide range of countries

decomposed into an output- a composition- and technique effect. In the case of trade reform, however, the composition effect is of a different nature, since openness to trade itself changes sectoral composition. A number of empirical studies suggest that openness reduces pollution (Wheeler and Martin, 1992; Birdsall and Wheeler, 1992), while others claim evidence to the contrary (Rock, 1995). Theoretical models have a different flavor, with results depending on whether pollution problems are national or transnational, and on the assumed regime for environmental management. Copeland and Taylor (1994) present a model in which pollution problems are national and national pollution control is optimal in both countries. It is, thus, a model with no coordination problem, emphasizing comparative advantage as in a traditional trade model. Then, one effect of openness is that the poor country will be offered a higher premium for undertaking polluting activities, the effect that is presumed in the pollution haven hypothesis. However, openness will also leave both countries wealthier, and thus more interested in changing both techniques and composition in the direction of less pollution.

Concerns along the lines of openness and pollution also touch on concerns for competitiveness, and the introduction of measures such as harmonization of environmental standards in trade negotiations. Kanbur, Keen and Wijnbergen show that coordination of environmental standards may be justified to avoid damaging "environmental competition", but suggest that (complete) harmonization would not be the preferred way of coordination. Extending such analysis with a supranational body such as the European Community, Ulph (1995) shows that information asymmetries between the higher body and the nations can lead to a greater harmonization than one would see in the case with full information. Markussen, Morey and Olewiler extend the open-economy analysis to include endogenous market structure. 
and activities are not available, we use energy consumption and the composition of fuel types as a proxy for emissions. We present evidence from the US to justify that fuel-and energy-intensity can be used as proxies for differences in pollution intensities within an industry.

Third, we test whether the pattern of outbound US investment during the 1980s and early 1990s can be explained by variations in pollution abatement costs across different sectors of the economy. If environmental legislation in the 1980s led to higher costs of doing business in the United States, then we would expect that foreign investment leaving this country would be concentrated in sectors where pollution abatement costs are significant.

Our focus is consequently on two related issues: (1) the impact of pollution abatement costs on the composition of foreign investment and (2) the role played by foreign investors in improving the environment by using more energy-efficient technology as well as cleaner sources of energy. Grossman and Krueger (1993) label these two issues as a "composition" and a "technique" effect. They show that NAFTA is likely to affect Mexico's environment by changing both the composition of output as well as the overall level of technology.

The remainder of the paper is organized as follows. Section II presents a simple modelling framework, describes the empirical specification, and discusses the data. Section III examines the factors which affect the stock of foreign investment in four developing countries. Section IV presents the methodology for analyzing the relative pollution intensity of foreign and domestic firms within an industry, and then presents the results. Section V presents the analysis of outbound US investment. Section VI concludes.

\section{II.1 Environmental regulation and the pollution haven hypothesis}

In this section, we present a simple theoretical model to study the factors determining the impact 
of pollution regulation in one country $(\mathrm{H})$ on investment and output by optimizing firms in $(\mathrm{H})$ and another country (A). The model has homogenous goods and we assume perfect competition (we relax the assumption of perfect competition in the empirical section which follows). To simplify notation we use a standard profit function, assuming that output price and its response is known. In our empirical implementation, however, since we do not observe output price, we introduce factors such as concentration ratios and protection measures, assuming that these affect profitability through their impact on the (unobserved) output price.

We show that the impact of abatement costs on industrial relocation is ambiguous. For example, if abatement costs fall with the scale of output, then the home country firm may find it more advantageous to expand locally when facing tougher environmental regulations.A market for a homogenous good is served by several types of firms: one type produces in country $H$ (in which environmental regulation occurs) and another produces abroad $(A){ }^{3}{ }^{3}$ The market is perfectly competitive, implying that firms with different cost structures adjust so that they have equal marginal costs.

Let the profits of a firm located in country $H$ be:

$$
\Pi^{H}=p x^{H}-C^{H}\left(x^{H}, k^{H}, a^{H}\right)-r k^{H}
$$

where $p$ denotes the price of output, $x^{H}$ denotes the firms' sales, $c^{H}$ is the firm's operating (i.e. short-run marginal) costs, $k^{H}$ denotes the firms's stock, $r$ is the cost of capital, and $a^{H}$ stands for pollution abatement--the resources needed to meet the country's pollution regulations. $c^{H}$ is continuous, twice differentiable and convex, so this will be the case for $\pi^{H}$ as well. We shall furthermore assume that short term marginal costs are positive $\left(\frac{\partial C^{H}}{\partial x^{H}} \geq 0\right)$, that capital reduces operating costs $\left(\frac{\partial C^{H}}{\partial k^{H}} \leq 0\right)$,

\footnotetext{
${ }^{3}$ The generalization to firms operating in several countries is obvious, and adds no relevant insights. The material in this section is from "Regulation and foreign investment: A more general model", available from the authors upon request.
} 
and that abatement increases operating costs $\left(\frac{\partial c^{H}}{\partial a^{H}} \geq 0\right)$.

\section{Figure 1}

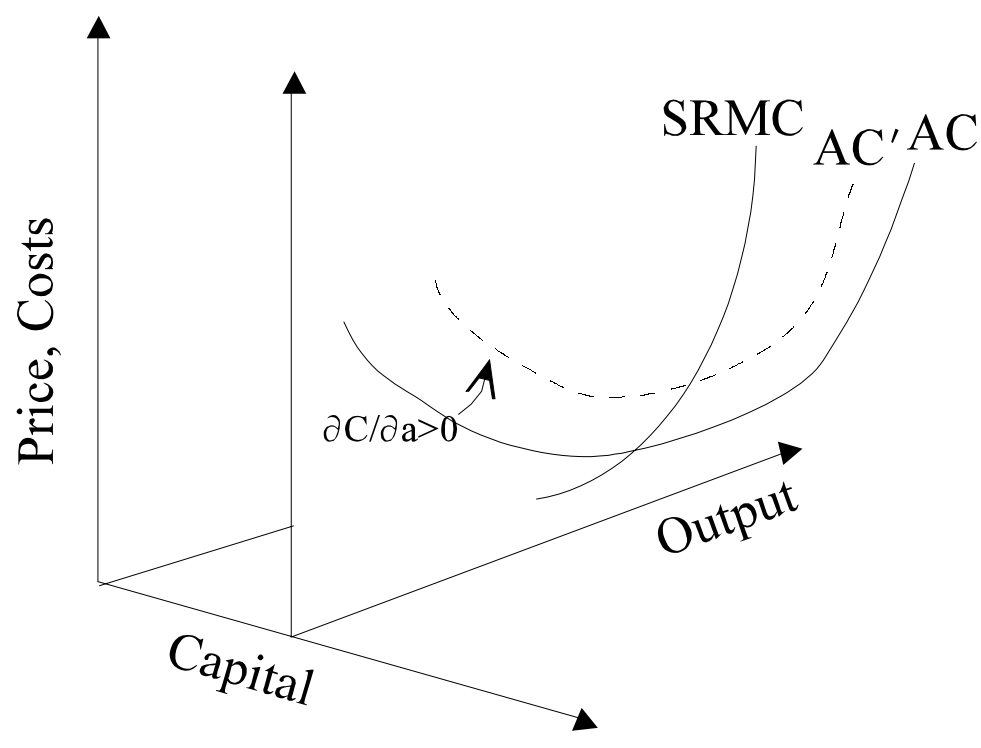

Most of the insights from this model can be gleaned from figure $1^{4}$. Short run marginal costs (SRMC) and average costs (AC) are drawn for the firm's present level of capital. A demand schedule is not drawn, but we assume that there are many other firms in perfect competition in the short run so the individual firm effectively faces infinitely elastic demand. Since the firm is in a short term equilibrium, it

\footnotetext{
${ }^{4}$ The model is solved by deducing the first-order conditions for profit maximum with respect to capital and output, differentiating these with respect to the regulatory parameter $a^{H}$, and finally solving for the effect on investment and output decisions. Details are shown in an Appendix, available from the authors upon request.
} 
will be somewhere on its short term marginal cost curve, SRMC. Furthermore, if the equilibrium is one with zero excess profits for the present level of capital, then the firm is on the lowest point of its relevant average cost curve, i.e. where the short term marginal cost curve cuts the average cost curve from below. Finally, if the firm is in a long run competitive equilibrium, then also the firm's capital will minimize average costs. In the three dimensions, however, the average cost surface will form a bowl, and a long run competitive equilibrium would imply that the firm's output and capital would be where SRMC cuts this bowl from below at its absolute minimum.

Environmental regulations are a part of this picture. The parameter $a^{H}$ represents a shift parameter controlled by the government which shifts total operating costs upwards - which also means that average costs shift upwards.

We develop results for the intermediate run, meaning that capital adjusts, but no condition of zero profit has been included:

$$
\frac{d x^{H}}{d a^{H}}=\frac{\left(\frac{d p}{d a^{H}}-\frac{\partial^{2} C^{H}}{\partial x^{H} \partial a^{H}}\right) \frac{\partial^{2} C^{H}}{\partial k^{H 2}}+\frac{\partial^{2} C^{H}}{\partial k^{H} \partial a^{H}} \frac{\partial^{2} C^{H}}{\partial x^{H} \partial k^{H}}}{\frac{\partial^{2} C^{H}}{\partial x^{H 2}} \frac{\partial^{2} C^{H}}{\partial k^{H 2}}-\frac{\partial^{2} C^{H}}{\partial x^{H} \partial k^{H}}}, \text { and }
$$

$$
\frac{d k^{H}}{d a^{H}}=\frac{-\left(\frac{d p}{d a^{H}}-\frac{\partial^{2} C^{H}}{\partial x^{H} \partial^{H}}\right) \frac{\partial^{2} C^{H}}{\partial k^{H} \partial x^{H}}-\frac{\partial^{2} C^{H}}{\partial x^{H 2}} \frac{\partial^{2} C^{H}}{\partial k^{H} \partial a^{H}}}{\frac{\partial^{2} C^{H}}{\partial x^{H 2}} \frac{\partial^{2} C^{h}}{\partial k^{H 2}}-\frac{\partial^{2} C^{H}}{\partial x^{H} \partial k^{H}}} .
$$


The denominator in (2) and (3) is positive by the second-order conditions for profit maximum, and the effect on output is ambiguous. To obtain the pollution haven result, it is sufficient (but not necessary) to assume that the output price does not change, $\frac{d p}{d a^{H}}=0$, that there is no interaction between capital and abatement, $\frac{\partial^{2} C^{H}}{\partial k^{H} \partial a^{H}}=0$, and that abatement increases marginal operating costs, $\frac{\partial^{2} C^{H}}{\partial x^{H} \partial a^{H}}>0$

Without these restrictive assumptions, however, a firm's output may increase simply because its marginal costs have increased less than the output price $^{5}$ or if there is an interaction between abatement and output. One such case would be if abatement makes more capital attractive-- such as when capital intensive technologies are less polluting and capital reduces marginal costs.

The effect of increasing abatement costs on capital investment is also ambiguous. It is possible that an increase in abatement costs could raise investment in the home country. One such possibility is when capital lowers abatement costs and marginal operating costs. In this framework, domestic investment could rise even if output falls, if a sufficiently large increase in capital intensity is induced.

As an illustration of these "complementarities", assume that a higher quality, more expensive furnace is available to a steel producer. It is more expensive, has lower emissions than the "normal" model and is also more energy efficient, so it will have lower variable costs once it is installed. Assume further that at low levels of environmental regulations, the higher energy efficiency is not sufficient to make the higher quality furnace attractive to the firm. Higher abatement requirements could make this

\footnotetext{
${ }^{5}$ We do not show the modeling of the output price, as it is awkward when there is heterogeneity among firms. As is apparent from equations (2) and (3), ambiguity with respect to sign remains even if we assume that the output price increases by as much as marginal operating costs are shifted upwards.
} 
cleaner technology attractive (increasing investment, and capital intensity in production), and output might then expand as a consequence of lower operating costs. The parameters of the model will determine whether the firm keeps the old furnace and pays higher abatement costs, invests in a new furnace and remains at home, or moves to another location and shuts down the existing plant. ${ }^{6}$

The ambiguous results (2) and (3) regarding the impact of environmental regulation on investment and output demonstrate that this issue can only be resolved through empirical analysis. However, the empirical tests below are implemented as reduced forms, since data for structural estimation (output price, for example) is not available. However, this framework is important because it shows that under reasonable assumptions we cannot predict whether there is likely to be a positive or negative relationship between foreign investment and pollution abatement costs.

\section{II.2 Empirical models of FDI}

In the simplified model above, the effect of environmental regulation on the location of polluting industries is ambiguous. In our empirical testing, we need to expand the framework to include other potential determinants of foreign investment. In this section, we describe how such determinants have been introduced in the literature and how they will be used in our subsequent analysis.

Although trade theories which predict the pattern of trade do not focus in general on ownership,

\footnotetext{
${ }^{6}$ We do not show the results for the plants abroad, as these are rather intuitive. The possibility that output and investment expands abroad as a result of environmental regulation at home, as supposed in the pollution haven hypothesis, exists. However, as it is possible that firms in the home country expand both investments and output, it is also possible that firms abroad reduce both output and investment - the opposite of what is assumed in the pollution haven hypothesis.

As an important example, consider the case in which i) capital at home is complementary to abatement (Then, ceteris paribus, abatement requirement makes more capital at home attractive); capital at home lowers short term marginal costs (Then, ceteris paribus, more capital at home makes higher production at home more attractive) and; iii) capital at home and abroad is substitutable. In this case, we could see the firm investing at home in order to make abatement requirements less expensive to comply with, taking advantage of the (thereby) reduced short term marginal costs by increasing output at home, and finally reducing capital abroad due to the substitutability of capital in the two locations. Such a structure would, thus, lead to the opposite effect of the pollution haven effect in both locations.
} 
the same factors which have been used to explain trade have also been used to explain foreign investment. For example, relatively higher labor costs should increase a country's imports of labor intensive goods from a relatively labor-rich country. This factor proportions explanation for trade has also been used to explain the pattern of foreign investment. Everything else equal, we would expect that foreign investors would locate in countries where factors they use in high proportions are cheaper than at home. This factor proportions theory for direct investment is described in more detail in Caves (1982), Helpman (1984) and more recently, in Brainard (1993). The importance of factor proportions in explaining the pattern of foreign investment can be captured through such variables as skill intensity, capital-labor ratios, and wage differentials between countries.

It is clear that factor proportions alone yield an unsatisfactory explanation of foreign investment. As Brainard and others have pointed out, the majority of foreign investment both originates from and locates in industrial countries. More recent theories about foreign investment focus on the role of ownership itself. An important role is played by "intangible assets" such as managerial abilities, technology and business relationships. This intangible asset theory of foreign investment has been developed by Horstmann and Markusen (1989) and others. The theory is the following: it is essential that the assets be intangibly related to the control of production; otherwise they can be sold at arms length or rented so that the link to plant ownership and control is severed. For example, in countries where patent protection is weak, research-intensive goods might be sold via direct investment rather than via a licensing agreement with a local firm. To capture the importance of such intangibles-which are often linked to advances in technology-as a motivation for foreign investment, we will use total factor productivity growth whenever such data is available.

A third framework has been described by Brainard (1997) as the proximity-concentration tradeoff between multinational sales and trade. According to Brainard, there are a number of factors (other than intangible assets or factor prices) which make it desirable to locate near the target market. These 
include tariff barriers and transport costs. A number of researchers have noted the attraction of protected domestic markets for foreign investment. A large share of foreign investment flows in the early 1990s, for example, were targeted either at the European Union in expectation of EC92 or at the US and Mexico in anticipation of NAFTA. Helleiner (1989), in his review of the role of foreign investment in developing countries, points out that "the prospect of large and especially protected local markets are the key to most import-substituting manufacturing firms' foreign activities". We will capture the importance of protected markets through measures of trade, such as import penetration or export shares.

Brainard (1997) points out, however, that there is a trade-off between the advantages of proximity and the benefits of concentrating production in one location. This is particularly true in sectors where there are economies of scale. We will, as is done elsewhere in the literature, capture the importance of scale economies with variables such as the numbers of employees per plant, and the Herfindahl index, which measures the size distribution of plants in a particular sector.

\section{Foreign Investment and Pollution Abatement in Four Developing Countries}

The Approach: In this section, we examine the pattern of foreign investment in four developing countries: Mexico, Morocco, Cote d'Ivoire and Venezuela. In Mexico and Venezuela, the majority of foreign investment originated in the United States; in Cote d'Ivoire and Morocco, most foreign investments are of French origin.

For all four countries, the following general specification was adopted for sector i and time t:

(4) $\mathrm{DFI}_{\mathrm{i}, \mathrm{t}}=$

$$
\begin{aligned}
& \alpha_{1} \mathrm{ABCOST}_{\mathrm{i}, \mathrm{t}}+\alpha_{2} \mathrm{IMPENET}_{\mathrm{i}, \mathrm{t}-1}+\alpha_{3} \mathrm{HERF}_{\mathrm{i}, \mathrm{t}-1}+\alpha_{4}\left(\mathrm{IMPENET}^{*} \mathrm{HERF}\right)_{\mathrm{i}, \mathrm{t}-1}
\end{aligned}
$$

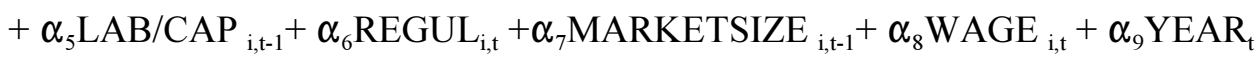

$$
\begin{aligned}
& +f_{\mathrm{i}}+\epsilon_{\mathrm{it}}
\end{aligned}
$$


The independent variables, which vary by four-digit sector, include pollution abatement cost (ABCOST); import penetration (IMPENET) as a proxy for openness in the sector's product market; the Herfindahl index (HERF), equal to the sum of the square of firm market shares in each sector, as a measure of scale and concentration; the interaction of market concentration and import penetration (IMPENET*HERF); the labor-capital ratio (LABCAP) in the sector; a measure of regulatory barriers against DFI (REGUL) which varies from 0 (no restrictions) to 2 (foreign investment prohibited); a measure of market size (MARKETSIZE), which is defined as the lagged share of domestic sales in the sector $j$ as a percentage of total manufacturing output; and wages in the sector $j$ (WAGE) in the United States (for Mexico and Venezuela) and France (for Morocco and Cote d'Ivoire). The variables IMPENET, HERF, LABCAP, and MARKETSIZE are all lagged one period to avoid potential simultaneity problems. We also allow for time effects (YEAR) and industry fixed effects.

Data Issues. The time period covered in the estimation is slightly different across the four countries. Cote d'Ivoire covers 1977 through 1987; Venezuela covers 1983 through 1988; and Morocco covers 1985 through 1990. In Mexico, although we have a panel of plants from 1984 through 1990, ownership information was only collected in 1990. Data is reported at the plant level, and when sector level estimates are needed, these are obtained by aggregating over plant observations, using a concordance to four-digit ISIC classification. Foreign investment is converted to a share variable by dividing by the total foreign investment in that country and year.

In 1987, the share of foreign investment in manufacturing varied from $38 \%$ in Cote d'Ivoire to 7 percent in Venezuela. Morocco lies somewhere in between: in 1988, foreign investment accounted for $15 \%$ of total assets in manufacturing. In 1990, foreign investment accounted for $10 \%$ of total assets in manufacturing in Mexico. Since these censuses typically only cover the largest plants, our measure of DFI may be biased. The smaller plants and informal sector plants are excluded, so it is likely that the 
importance of foreign investment in the manufacturing sector as a whole may be over-stated. For Mexico, the sample excludes many "maquiladora" plants--firms under special arrangements to assemble inputs imported from the United States for re-export.

The independent variables vary across industrial subsectors and over time. For all four countries, all dependent and independent variables were redefined to be consistent with the ISIC classification, including US abatement costs. Import penetration, the Herfindahl index (HERF), the labor-capital ratio (LABCAP), and market size were calculated using both the censuses and trade information from the source country. The measure of regulations against DFI (REGUL) was taken from both policy reports and various publications for potential investors. Manufacturing wages by sector and time period in France and the United States were taken from ILO publications.

The data source for pollution abatement expenditures is the Manufacturers' Pollution Abatement Capital Expenditures and Operating Costs Survey (referred to as the PACE survey) administered by the U.S. Department of Commerce. Following earlier studies, we defined pollution abatement costs as the dollar amount of operating expenditures normalized by industry value-added. We feel justified in excluding capital expenditures for several reasons. First, the majority of abatement expenditures are for operating costs, not for capital expenditures. Second, the pattern of costs across industries is very similar across operating and capital costs. Data was available for 1976 through 1993, excluding 1987 when no survey was conducted. Since pollution abatement costs were not available for France, we used the same abatement cost measure in all four host countries. By using the same measure of abatement costs, we are assuming that abatement costs follow a similar pattern across sectors in the United States and in other "host" countries.

\footnotetext{
7 This assumption is supported by Sorsa (1994), who finds that differences in environmental spending among industrial countries are minor. We also assume that the pattern is a good proxy for the pattern of cost savings associated with localizing production in the host country. While the validity of these two assumptions cannot be tested separately, we will test the hypothesis that the sectoral distribution of foreign investment is positively associated with high abatement costs in the U.S., against the alternative hypothesis that there is a negative or no association.
} 
Results: The results are reported in Table 1. In columns (8) and (9), we pool all four countries, but include country dummies to allow for systematic differences across countries. For both the pooled sample and the individual country results, we report the estimates with and without year and industry effects. We also report the results of a Hausman test for whether random or fixed effects are more appropriate. The results of the Hausman test suggest that a fixed effect specification is warranted for Cote d'Ivoire and Morocco, but not for Venezuela or the full sample. For Mexico, however, the data is only available as a cross-section for 1990. Consequently, we cannot control for time and industry effects.

Across all specifications, pollution abatement costs do not have a systematic impact on the pattern of foreign investment. Although there is a significant positive relationship between abatement costs and foreign investment in Cote d'Ivoire, the relationship is significant and negative for Venezuela. Both relationships become insignificant with the introduction of fixed effects, although a critic could argue that this indicates that there is not enough time series variation in the data. The data appear to suggest no robust association between the pattern of pollution abatement costs and investment. Other factors, however, significantly affect the pattern of investment. For example, the results show that import penetration is negatively related to DFI, suggesting that foreign investors locate in sectors with little competition from imports. The results also point to a negative correlation between the Herfindahl index and DFI, suggesting that foreign investors are less likely to locate in concentrated sectors typically characterized by entry barriers and economies of scale.

In all four countries, the single biggest draw for foreign investors was the size of the domestic market. Foreign investors tend to concentrate in sectors with large total sales. However, controlling for market size could be unjustified if the size reflects that domestic firms also invest in pollution-intensive activities--reflecting a country's comparative advantage in producing "dirty" products. Consequently, the analysis was redone excluding MARKETSIZE. Although excluding MARKETSIZE affects the magnitude of some of the coefficients, it does not alter our basic results: that the coefficient on abatement 
costs is not consistently significant across specifications. ${ }^{8}$

Using Measures of Pollution Intensity: To test whether the costs of environmental regulations lead firms to move plants abroad, this paper focuses on the relationship between pollution abatement costs and the pattern of foreign investment. An equally interesting, but slightly different question would be to ask whether "dirtier" sectors--measured using actual pollution emissions--are more likely to attract foreign investors. ${ }^{9}$ We thus redid the analysis using three different measures of pollution emissions: total particulates, which is a measure of air pollution; biological oxygen demand, which is a broad measure of water pollution; and total toxic releases..$^{10}$

Total particulates (TP), which captures small and large dust particles, is closely related to phenomena such as the (now historic) London smog, and to air pollution in cities with emissions from fuel- and diesel oil combustion, from energy-intensive processes such as steel and cement, from twostroke engines, coal use, and burning of wood and residues. Analysis in the World Bank and elsewhere indicates that particulates is the main air pollution problem (as judged by health impact) in many third world cities (See, for instance, World Bank 1992, Ostro 1994 and Ostro et al 1994). Biological Oxygen Demand (BOD) indicates how discharges to water bodies deplete their oxygen levels, and is widely accepted as a broad measure of water pollution. Total toxic releases (TOX) is an unweighted sum of releases of the 320 compounds in the U.S. EPA's toxic chemical release inventory. All of these measures are by weight. In order to normalize, emissions are divided by the total output of the firm, measured in monetary terms, to arrive at sector-specific emission intensities for the three pollutants.

Regretfully, no comprehensive data on manufacturing emissions exists for developing countries.

\footnotetext{
${ }^{8}$ It is not surprising that excluding MARKETSIZE fails to affect the coefficient on abatement costs, since there is no reason to believe that there is any correlation between the two.

${ }^{6}$ One might conjecture that industries with high abatement costs are industries with high pollution intensities, but this need not be the case, given that abatement could be effective in removing pollution. If abatement is socially optimal, then an industry will be ranked high in terms of abatement costs and low in terms of pollution intensity if marginal benefits equal marginal costs at a point with much abatement and little remaining pollution.

${ }^{7}$ See Hettige, Martin, Singh and Wheeler, (1995) for more details on the database.
} 
We assume that the sector specific emission intensities estimated from data on manufacturing in the United States can serve as proxies for the relative emission intensities for the same sectors within the LDC host countries. Sector specific emissions intensities are calculated using a plant-level data set resulting from a merger of data sets of the Bureau of the Census and U.S. EPA ${ }^{11}$.

Such "imported" emission intensities (for individual inputs, technologies, or outputs, as applied here) are routinely used in environmental analysis when local and more specific emission measurements are not available. ${ }^{12}$ It may certainly be argued that emission intensities are higher in developing countries, due to less progress with emission controls, older technologies and lower skill levels. The working hypothesis is still plausible, however, that relative emission intensities among sectors are similar across countries. It is certainly the case that industries such as cement, industrial chemicals, fertilizer and pesticides, pulp and paper, refineries and primary metals--which have the highest abatement costs in the U.S--are the same industries where abatement costs are high in other industrialized countries (See Sorsa, 1994). Briefly stated, we assume that these sectors in developing countries are also likely to be heavy polluters.

Table 2 reports the correlations between the three measures of emission intensity and pollution abatement costs. The table shows that, in a comparison among 4-digit ISIC sectors in the US, there is no significant correlation between air pollution, water pollution, and toxicity. Thus, although these three measures of pollution are very broadly defined, there is no general tendency that a sector which pollutes in one medium also pollutes another medium. However, Table 2 does report a statistically significant correlation between abatement costs and toxic releases. Industries which on average have high

\footnotetext{
${ }^{8}$ The emissions data are from three separate data-bases generated by the United States Environmental Protection Agency (U.S. EPA): The Aerometric Information Retrieval System (Air), The National Pollutant Discharge Elimination System (water) and the Toxic Chemical Release Inventory (irrespective of medium). These have been linked with the Longitudinal Research Data Base on manufacturing firms (Bureau of the Census, Center for Economic Studies) by a World Bank research project: The Industrial Pollution Projection System (IPPS), see Hettige, Martin, Singh and Wheeler, 1995.

${ }^{9}$ Such transferred intensities and coefficients are used in engineering analysis as well as in more superficial economic analysis, and in industrial as well as developing countries. See, for instance, for engineering analysis, U.S. EPA's AP-42, on industrial emission coefficients for air pollution.
} 
abatement costs typically also emit toxic substances.

Table 3 repeats the specification in Table 1, but explores alternative specifications and also replaces pollution abatement costs with our three different measures of emission intensities. The three alternative specifications which continue to use pollution abatement costs explore the consequences of allowing for group-wise heteroskedasticity (row (1)), first-order serial autocorrelation in the error term (row(2)), and Generalized Method of Moments (GMM) estimation (row(3)). We employed a GMM estimator to jointly address serial correlation and potential endogeneity of the herfindahl index, import penetration, capital-labor ratios and market size. If we make these econometric corrections, we find that pollution abatement costs have no significant or systematic impact on the pattern of foreign investment, either with or without industry dummies. The GMM results are particularly unsatisfactory, leading to large changes in the coefficient on abatement costs and enormous standard errors. In large part, the poor estimates using GMM stem from the short panel nature of the data; efforts to use lags as instruments for right-hand side variables such as market size, the capital/labor ratio, concentration and import penetration led to very small sample sizes. These results reinforce our conclusions that there is no systematic relationship between pollution abatement costs and the pattern of foreign investment.

In the remaining three rows, we report the coefficients on the three measures of pollution emissions. We do not report the coefficients on the other variables ( which are similar to those reported in Table 1, and not of primary interest). We report the results both with and without industry and time dummies. Since our emission intensity proxies do not change over time (in contrast to pollution abatement costs, which vary across industries and over time) the panel estimates without industry dummies are most meaningful.

For two out of the three emission measures, the relationship between emissions and the pattern of foreign investment is either insignificant or negative--high levels of water pollution (proxied by BOD), for example, are associated with less foreign investment, not more. The only exceptions are toxic 
emissions in Cote d'Ivoire and air pollution in all three countries: SUSSPART is significantly and positively correlated with the pattern of foreign investment, particularly if we do not control for sector and time effects.

Using measures of emissions instead of actual abatement costs, we conclude that there is some evidence that high-emission sectors attract foreign investors, particularly if emissions are measured in terms of air pollution. There is a significantly positive association between air pollution and the pattern of foreign investment in several countries, even after controlling for other factors. However, using other measures of emissions, such as measures of water pollution or toxicity, the pattern is reversed: foreign investment is less likely in sectors where emissions are higher.

\section{Energy use and pollution intensity}

Our discussion so far ignores one potential benefit from the entry of industrial country firms into developing countries. If industrial country plants use cleaner technology than their local peers, they may help the host country environment. This would be true if foreign entrants replace older, "dirtier" local competitors, and even more so if they also influence domestic plants in their choice of fuels or technology. Unfortunately, data on emissions by ownership is not currently available for our four sample countries. One way to address the problem is to find a plant-level proxy for emissions. In this section, we propose using fuel and energy intensity as a proxy for emissions at the plant level. We first make the case for these proxies using evidence from the U.S.

The standard reference in the technical literature on this topic is EPA's handbook AP-42, which

prescribes emission factors for various industrial processes (combustion and others). For most processes, AP-42 proposes an emission function (or a range, given that a limited number of measurements have given widely varying results), as follows: 


$$
e_{i}=e_{i}\left(x_{1}, x_{2}, \ldots, x_{n}, a_{j}, t_{j}\right),=\sum_{j} f_{i j}\left(a_{j}, t_{j}\right) \cdot x_{j} \cdot
$$

(where $e_{i}$ are emissions of pollutant $i$ (say dust, in kilograms), $x_{j}$ is the quantity of fuel $j$ (say diesel oil, in tons), $a_{j}$ is a variable denoting the type of abatement equipment in place, if any (say, filters, precipitators, baghouses), and $t_{j}$ is (a vector) denoting other relevant aspects of technology and equipment. In our work we shall use energy intensity, defined as energy use per unit of output, as a proxy for emissions.

We shall show that even in the U.S., where respectable air pollution control programs have been in place for more than 20 years, and the choice of fuels and electricity is very varied, there is a strong statistical relationship between air pollution coefficients and energy use. Due to the lower prevalence of emission control devices in developing countries, and the likely lower variation in fuel choice within an industry, the relationship between air pollution and energy use in these countries is likely to be even stronger. ${ }^{13}$

We begin by presenting the evidence on the relationship between energy use and pollution emissions across U.S. industries. As in the earlier tables, we use three different measures of emissions: particulates, which measure air pollution; BOD, which measures water pollution; and toxics. As before, particulates are defined as annual pounds of particulates divided by thousands of dollars of total output in the sector. BOD intensity is defined as daily kilograms per thousands of dollars of output. Two different measures of toxics are reported, TOXLB and TOXUB. Both measures are computed as annual pounds of toxics divided by total output in thousands of dollars. TOXLB ("lower bound"), however, is computed using total toxics reported by the Toxic Release Inventory (TRI), divided by total output in the sector. TOXUB ("upper bound") is computed using only those plants present in both the TRI database and the

\footnotetext{
${ }^{13}$ Guo and Tybout (1994), Moss and Tybout (1994) and Eskeland, Jimenez and Liu (1994) have studied fuel choice in Chile and Indonesia, data bases in which details on fuel choice is available, but ownership data is not.
} 


\section{LRD database.}

The rank correlations between these alternative measures of emissions and different factor inputs, including energy, are reported in Table 4. We report the correlations between emissions and six different factor inputs: the share of unskilled labor in total value of shipments, the skilled labor share, capital share, manufactured input shares, raw material input shares, and the share of energy inputs in total output. Energy use is highly correlated with different measures of emissions. The correlation between energy use and particulates is .58 ; between toxics and energy use the correlation varies between .52 and .55. The correlation with BOD is lower, though also significantly different from zero, at .22. Table 4 also shows that the correlation between pollution and energy use is much higher than for other factor inputs.

Yet even if energy intensity could provide a good proxy for emissions across industries, energy intensity may not be a good proxy for differences in emissions between plants within the same industry. To investigate this issue, we used a cross section of U.S. manufacturing firms to examine the relationship between different types of factor inputs and plant-specific emissions, one industry at a time.

The results are reported in Table 5. The strength of the relationship between energy use and emissions varies with the type of industry. In a cross section of all firms, including SIC sector dummies, energy intensity is a strong predictor of particulates emission. However, when the relationship is estimated in a separate equation for each of the 17 SIC industries, emissions of particulates are highly correlated with energy use at the plant level for only four industries: chemicals, petroleum refining, lumber and wood products, and non-electrical machinery. Two of the most polluting activities in manufacturing--chemicals and petroleum refining--are included in these four sectors. The results presented in Tables 4 and 5 suggest that although energy intensity is highly correlated with particulates emissions overall, the correlation is based on a strong relationship between emissions and energy use in 
four industries ${ }^{14}$. In the section that follows, we restrict our analysis to only those four sectors where energy use serves as a reasonable proxy for emissions.

The framework for the estimation is is based on a translog approximation to a production function. W assume that each plant j's output in time $\mathrm{t}, \mathrm{Y}_{\mathrm{jt}}$, is given by $\mathrm{Y}_{\mathrm{jt}}=f\left(L_{s}, L_{w}, K, M, E, T\right)_{j t}$ where $\mathrm{Y}$ is total value of output, $L_{s}$ is equal to the number of skilled workers, $L_{u}$ is equal to the number of unskilled workers, $\mathrm{M}$ is the amount of material inputs, $\mathrm{E}$ is the quantity of energy, and $\mathrm{T}$ is an index of technology. With these 5 inputs and our index of technology $\mathrm{T}$ (we can denote each input as well as the technology index as $\mathrm{v}_{\mathrm{i}}$ ), we can approximate $\mathrm{Y}$ by the following translog function:

$$
\ln Y_{j t}=a_{0}+\sum_{i} b_{i} \ln v_{i j t}+1 / 2 \sum_{i} \sum_{m} b_{i m} \ln v_{i j t} \ln v_{m j t}+\epsilon_{j t}
$$

where $\epsilon$ is a disturbance term. Inverse input demands are obtained in share form by differentiating (6) with respect to each input. Differentiating (6) with respect to $\ln E$, where E represents the quantity of energy used by the plant, yields an equation for energy's share in output, which we also refer to as "energy intensity":

$$
\left(W_{e} E_{e} / P Y\right)_{j t}=S_{e j t}=b_{0}+b_{l} \ln L_{s j t}+b_{2} \ln L_{u j t}+b_{3} \ln K_{j t}+b_{4} \ln M_{j t}+b_{5} \ln E_{j t}+\phi T_{j t}+v_{j t}
$$

Energy's share in the total value of the plant's output, PY, is equal to the price of energy $\mathrm{W}_{\mathrm{e}}$ multiplied by its quantity $\mathrm{E}_{\mathrm{e}}$, divided by PY. This is a function of the (log) quantity of all inputs, which in our data include skilled and unskilled workers, materials, capital stock, and energy. We assume that

\footnotetext{
${ }^{14}$ As one referee pointed out, the r-square in the regressions which examine the relationship between energy intensity and emissions varies significantly. The referee argued that much of the variation in emissions is unexplained by energy intensity, with the exception of chemical producers (see Table 5). Consequently, we also redid the results reported in Table 6, limiting the sample to chemical producers. The results are almost identical: multinationals in the chemical sector consume less energy as a share of output, and their energy use is more skewed towards electricity use.
} 
technological change is a function of the plant's age, ownership structure, investment in research and development, and imported machinery (which can embody technological change). This yields the final estimating equation:

$$
\begin{aligned}
& \left(W_{e} E_{e} / P Y\right)_{j t}=S_{e j t}=b_{0}+\gamma_{1} F O R_{j t}+\gamma_{2} P U B_{j t}+\gamma_{3} A G E_{j t}+\gamma_{4} M A C H I M P_{j t}+\gamma_{5} R N D_{j t}+ \\
& b_{l} \ln L_{s j t}+b_{2} \ln L_{u j t}+b_{3} \ln K_{j t}+b_{4} \ln M_{j t}+b_{5} \ln E_{j t}+v_{j t}
\end{aligned}
$$

Table 6 presents evidence on the determinants of energy intensity at the plant level. In this estimation, we include only plants in the chemical, petroleum refining, wood and lumber, and nonelectrical machinery sectors, since these were the sectors for which the proxy was significant when comparing plants within sectors in the U.S. data sets. Independent variables include ownership, plant size, capital intensity, age of the plant, machinery imports, research and development, and the electricity price. Morocco is excluded from the analysis due to lack of information on plant-specific energy use. Since data availability varies across the three data sets, not all variables could be included for each country. The data from all four sectors are pooled, and all estimates include sector dummies at the four-digit SIC level.

Table 6 reports results on two separate tests. First, we measured the determinants of energy intensity, defined as the share of energy inputs in total output (in value terms) for each plant. Second, we examined the extent to which ownership affects the use of cleaner types of energy--in particular, electricity. The negative and statistically significant coefficient on foreign ownership (see column (1) of Table 6 for each country) shows that foreign ownership is associated with lower levels of energy use in all three countries. To the extent that energy use is a good proxy for air pollution emissions, this suggests that foreign-owned plants have lower levels of emissions than comparable domestically owned plants. The results are robust to the inclusion of plant age, number of employees, and capital intensity--suggesting that foreign plants are more fuel efficient even if we control for the fact that foreign plants tend to be 
younger, larger, and more capital-intensive.

We also test (see column (2)) whether foreign ownership is associated with using "cleaner" types of energy. For all three countries, we test whether foreign firms have a higher share of electricity in their energy bill. We also redid the analysis limiting the sample to chemical firms, which show a very high correlation between energy intensity and emissions in Table 5. As pointed out in footnote 14, the results were unaffected. For all three countries, we find that foreign ownership is associated both with less energy use as well as with the "cleaner end" of the range of energy types. ${ }^{15}$

\section{The Impact of Pollution Abatement Costs on US Outbound Foreign Investment}

One possible criticism of the results presented earlier is that we do not distinguish foreign direct investment by country of origin. We assume that most DFI originates in industrialized countries, and that the distribution of abatement costs in industrialized countries is similar to the pattern in the United States. Although both assumptions are plausible, in this section we address these problems by examining foreign investment originating in the United States.

If environmental legislation has led to higher costs of doing business in the United States, then we would expect that foreign investment leaving this country would be concentrated in sectors where pollution abatement costs are high. One simple way to test this hypothesis is to measure the statistical correlation between the pattern of outbound foreign investment and pollution abatement costs across different sectors. In the United States, the Department of Commerce gathers information on both the stock and flow of outgoing foreign investment, and publishes the data at the level of three-digit SIC sector

\footnotetext{
${ }^{15}$ At the point where it is used, electricity is a "clean" fuel, though it may be more or less polluting than others where it is produced (See Eskeland, Jimenez and Liu, 1994).
} 
codes. ${ }^{16}$ For the manufacturing sector, the PACE survey described earlier was used as a source for pollution abatement expenditures.

Foreign investment outflows were available for 1982 through 1993, recorded on a historical cost basis. As earlier, to normalize the foreign investment data, we divided investment for each three digit sector by the year's total for foreign investment. ${ }^{17}$ Consequently our foreign investment data measures the distribution of direct foreign investment (DFI) across sectors. We also redid the analysis using other measures of foreign investment, such as foreign investment income and sales. However, since using these alternative measures did not affect our results, they are not reported in the paper.

Using data for the 1982-1993 period, we estimated the strength of the relationship between the pattern of foreign investment and pollution abatement costs in several different ways. The results are reported in Table 7 . We began by regressing annual foreign investment outflows on pollution abatement costs, without controlling for other factors. Pollution abatement costs were measured, as before, as the sectoral share of abatement costs in manufacturing value-added.

As indicated in Table 7, there is a statistically significant correlation between abatement costs and the pattern of foreign investment if no control variables are included. The results are similar if foreign investment is measured as a flow (column (1)) or as a stock (column (4)). The magnitudes, however, are small. If abatement costs doubled from a mean of 1.3 percent of value-added, the distribution of outbound DFI would move towards dirtier industries by 0.2 to one half of 1 percent.

In the remaining columns, we include other variables which also affect the pattern of foreign

\footnotetext{
${ }^{16}$ The time series data on outbound U.S. DFI is not reported by recipient country. Thus, a detected pattern on this data would have to reflect a general tendency for DFI to locate in countries with less abatement costs, since one cannot distinguish recipient countries.

${ }^{17}$ Although both DFI and abatement costs are recorded using the same Standard Industrial Classification (SIC), SIC codes were revised in 1987. New codes were added and others were deleted, making it difficult to create an unbroken time series for the whole period. We addressed this problem by deleting SIC codes where the change in classification creates a time series which is not comparable before and after 1987. This led to the elimination of about 30 percent of the SIC codes with available data.
} 
investment. Although some of the controls are the same as those used in the first section of the paper, others differ because the question we are now asking is somewhat different. In particular, we are now focusing on the characteristics of the sectors in the source country, rather than the characteristics of the sectors in the host country, to understand the pattern of US outward bound foreign investment.

Consequently, we continue to include the source wage and pollution abatement costs in the US. We also include other factors which could not be identified in the first part of the paper. To capture the role of factor endowments in the source country, we included the labor/capital ratio. If foreign investors move abroad to find cheap factors, then we would expect that in a capital-rich country like the United States, more labor-intensive sectors would be more likely to relocate. Labor is measured as total number of employees, while capital is the real capital stock. This measure is lagged one period to avoid endogeneity problems. Total factor productivity productivity growth (TFPG) captures the importance of intangible assets in motivating foreign investment. We also include import penetration (lagged) as an alternative measure of intangible assets. We would expect that sectors with a high degree of import penetration in the USA are not sectors where US multinationals have a high degree of intangible assets. Scale economies are proxied by the number of employees per firm (SCALE).

Without more detail on the destination of foreign investment, it is difficult to formulate measures of protection in destination markets, although outbound exports from the United States could be a measure of a sector's openness. If foreign investment is attracted to protected sectors and markets that are "protected" either through trade policies or large transport costs, we would expect a negative relationship between US exports and the pattern of outbound foreign investment. Exports (lagged) are measured as the share of export sales in total U.S. output.

If we introduce these additional variables, the relationship between abatement expenditures and the pattern of outbound US investment becomes insignificant if DFI is measured as a flow. However, the relationship between the stock of foreign investment and pollution abatement costs remains barely 
significant. The addition of these control variables suggests that the relationship between abatement expenditures and the pattern of outbound US investment is not a robust one.

Adding time and industry dummies further reduces the statistical significance of the abatement cost variable, which then becomes insignificant if DFI is measured as a stock. If DFI is measured as a flow, the sign on abatement costs becomes negative and significant, suggesting more outbound foreign investment in sectors where abatement costs as a share of value-added is falling. This result suggests that sector-specific changes in abatement cost are not significantly associated with outbound U.S. DFI. Although some other variables retain their significance in explaining the pattern of foreign investment, adding time and industry dummies generally reduces the statistical significance of all the variables. One interpretation is that pollution abatement costs are not strongly associated with the pattern of foreign investment. An alternative interpretation, particularly for the results in columns (3) and (6), is that there is not sufficient sector-specific time variation in the panel. When we add year and industry dummies to the specification using direct investment stocks, the R-square climbs to .99. This suggests that most of the variation in the stock of DFI is primarily explained by year and industry effects, and that there is not sufficient variation in the data. Nevertheless, there were significant changes in foreign investment during this period. For example, between 1982 and 1993 mean foreign investment shifted annually from one sector to another by 2 percent and the standard deviation was 3 percent; some sectors experienced annual reductions as large as 25 percentage points of overall FDI, others increased by 24 percentage points. Abatement costs on an annual average changed by .2 percent of value added with a standard deviation of .3 percent; again, some sectors experienced large reductions (of 4 percent) while in other sectors the value-added share of abatement costs rose by 4 percentage points.

Future research in this area should attempt to build a longer time series and should also attempt to break down FDI stocks and flows according to country of destination. To the extent that the pollution haven hypothesis applies primarily to developing countries, it would be useful to examine the relationship 
between outward FDI to those countries and abatement costs. Once detailed data on outward foreign investment over time, by destination country, and by subsector is made available, this exercise will be possible.

The results in Table 7 suggest that it is difficult to find a robust relationship between the magnitude of expenditures on pollution abatement and the volume of US investment which goes abroad. In addition, the point estimates suggest that any impact of abatement costs on the distribution of DFI is very small, if not zero. These results are not surprising in light of the fact that pollution abatement expenditures are only a small fraction of overall costs. For example, in the dirtiest industries, abatement costs accounted for less than 10 percent of value-added. During our sample period, abatement costs in paper mills accounted for 5 percent of value-added, while abatement costs in organic and inorganic chemical plants accounted for 8 percent of value-added. This evidence appears to confirm the conclusions reached by earlier studies such as Walter (1982), who argued that other factors (such as market size or political risk) were simply more important in determining industrial relocation.

\section{Concluding Remarks}

This paper tests whether multinationals are flocking to developing country "pollution havens" to take advantage of lax environmental standards. We begin by examining the pattern of foreign investment in four developing countries: Mexico, Venezuela, Morocco and Cote d'Ivoire. This approach allows us to control for country-specific factors which could affect the pattern of foreign investment. Using a number of different measures of pollution, we find some evidence that foreign investors are concentrated in sectors with high levels of air pollution, although the evidence is weak at best. We find no evidence that foreign investment in these developing countries is related to abatement costs in industrialized countries. We proceed to test whether, within industries, there is any tendency for foreign firms to pollute less or 
more than their local peers. Our proxy for pollution intensity is the use of energy and 'dirty fuels', and we find that foreign plants are significantly more energy efficient and use cleaner types of energy.

We then turn to an analysis of the 'originating country' by examining the pattern of outbound US investment between 1982 and 1993. Although there is some evidence that the pattern of US foreign investment is skewed towards industries with high costs of pollution abatement, the results are not robust to the inclusion of other variables. Once we include other controls in the analysis or allow for industry effects, the results are reversed: outbound foreign investment is highest in sectors with low abatement costs.

Our theoretical model indicates that the pollution haven hypothesis is unambiguous only in a very simplistic model. In a more realistic model the effect of regulation on foreign investment could be either positive or negative, depending on complementarities between abatement and capital. For example, if per unit abatement costs fall with the scale of output, then the home country firm may expand at home as it implements pollution abatement in response to regulations. Thus, our finding of no robust correlation between environmental regulation in industrialized countries and foreign investment in developing countries need not reflect that relocation due to environmental regulation is 'too small' to be noticed in the data set. The relationship between investment and regulation is not as simple as assumed in a naive model. It depends on a number of factors, the combined effects of which may be positive, zero or negative.

We also find that foreign firms are less polluting than their peers in developing countries. This does not in any way mean that 'pollution havens' cannot exist, or that we should cease to worry about pollution in developing countries. However, our research does suggest that policy makers should pursue pollution control policy focusing on pollution itself, rather than on investment or particular investors. 
Bibliography

Birdsall, Nancy and David Wheeler (1992). Trade Policy and Industrial Pollution in Latin America: Where are the Pollution Havens?" In International Trade and the Environment, World Bank Discussion Paper No. 159, Patrick Low (Editor), The World Bank, Washington, D.C.

Brainard, S. Lael (1993). "An Empirical Assessment of the Factor Proportions Explanation of Multinational Sales.” National Bureau of Economic Research Working Paper Number 4583.

Brainard, S. Lael (1997). “An Empirical Assessment of the Proximity-Concentration Trade-off Between Multinational Sales and Trade." The American Economic Review, 87(4) September 1997, 520$\underline{44 .}$

Caves, Richard (1982). Multinational Enterprise and Economic Analysis. Cambridge: Cambridge University Press.

Copeland, Brian R. and M. Scott Taylor (1994). "North-South Trade and the Environment." Quarterly Journal of Economics, Vol. 109, No. 3, 755-787.

Dean, Judith M. (1992). "Trade and the Environment: A Survey of the Literature". Background Paper No. 3, World Development Report, Washington, D.C.

Eskeland Gunnar S. (1994). "A Presumptive Pigovian Tax: Complementing Regulation to Mimic an Emissions Fee". The World Bank Economic Review, Vol. 8, No. 3: 373-394.

Eskeland, Gunnar S., Emmanual Jimenez and Lili Liu (1994). "Energy Pricing and Air Pollution:

Econometric Evidence from Manufacturing in Chile and Indonesia". Policy Research Workin Paper Series 1323. World Bank, Policy Research Department, Washington, D.C.

Glomsroed, S., T. Johnsen and H. Vennemoe (1992). "Stabilization of CO2: A CGE assessment".Scandinavian Journal of Economics, 94 (1), 53-69.

Guo, Charles C. and James R. Tybout (1994). "How Relative Prices Affect Fuel Use Patterns in Manufacturing: Plant-Level Evidence from Chile". Policy Research Working Paper Series 1297. World Bank, Policy Research Department, Washington, D.C.

Grossman, Gene M. a nd Alan B. Krueger (1993). "Environmental Impacts of a North American Free Trade Agreement". In The U.S.-Mexico Free Trade Agreement, P. Garber, ed. Cambridge, MA: MIT Press.

Grossman, Gene M. and Alan B. Krueger (1995). "Economic Growth and the Environment". Quarterly Journal of Economics, Vol. CX, No. 2, 353-377.

Helleiner, Gerald K (1989). "Transnational Corporations and Direct Foreign Investment". In HollisChenery and T.N. Srinivasan, eds., Handbook of Development Economics, vol. 2, chap. 27. Amsterdam: North-Holland. 
Hettige, Hemamala, Paul Martin, Manjula Singh, and David Wheeler (1995). "The Industrial Pollution Projection System". Policy Research Working Paper 1431. World Bank, Policy Research Department, Washington, D.C.

Horstmann, Ignatius J. and James R. Markusen (1989). "Firm-Specific Assets and the Gains from Direct Foreign Investment". Economica, February, 56(2210, 41-48.

Jorgenson, D.W. and Peter J. Wilcoxen (1993). "Reducing US carbon dioxide emissions: An econometric general equilibrium assessment". Resource and Energy Economics, 15, 1-25.

Leonard, H. Jeffrey (1988). "Pollution and the Struggle for the World Product: Multinational Corporations, Environment, and International Comparative Advantage", $\underline{\text { Cambridge University }}$ Press, Cambridge.

Low, Patrick and Alexander Yeats (1992). "Do "Dirty" Industries Migrate?" In International Trade and the Environment. Sponsored by International Trade Division, International Economics Department, The World Bank, November 21-22. Washington, D.C.

Manne, Alan S. and Richard G. Richels (1990). "CO2 Emission Limits: An Economic Cost Analysis for the USA". The Energy Journal, Vol. 11 No. 2.

Markusen, James R., Edward R. Morey and Nancy D. Olewiler (1993). "Environmental Policy when Market Structure and Plant Locations are Endogenous". Journal of Environmental Economics and Management, 24, 69-86.

Moss, Diana, and James Tybout (1994). "The Scope for Fuel Substitution in Manufacturing Industries: A Case Study of Chile and Colombia". World Bank Economic Review 8(1): 49-74.

Motta, Massimo and Jacques-Francois Thisse (1994). "Does Environmental Dumping Lead to Delocation?" European Economic Review, 48, 563-76.

Ostro, Bart (1994). "Estimating Health Effects of Air Pollution: A Methodology with an Application to Jakarta", Policy Research Working Paper Series 1301. World Bank, Policy Research Department, Washington, D.C.

Ostro, Bart, Jose Miguel Sanchez, Carlos Aranda, and Gunnar S. Eskeland (1994). "Air Pollution and Mortality: Results from a Study of Santiago, Chile", Policy Research Working Paper Series 1453. World Bank, Policy Research Department, Washington, D.C. Also in Journal of Exposure Analysis and Environmental Epidemiology, Vol. 6, 1996, 97-114.

Pearson, C. (1987). Multinational Corporations, Environment, and the Third World. Durham:Duke University Press.

, (1985). Down to Business: Multinational Corporations, the Environment, and Development. Washington, D.C.: World Resources Institute. 
Rock Michael T. (1995). "Pollution Intensity of GDP and Trade Policy: Can the World Bank be Wrong?".

World Development, Vol. 24, No. 3, 471-79.

Selden, Thomas M., and Daqing Song (1994). "Environmental Quality and Development: Is There a

Kuznets Curve for Air Pollution Emissions?" Journal of Environmental Economics and

Management, XXVII, 147-62.

Sorsa, Piritta (1994). "Competitiveness and Environmental Standards: Some Exploratory Results".

World Bank Policy Research Working Paper Series, No. 1249, The World Bank, February.

U.S. Department of Commerce, Bureau of Census, various issues, Manufactures' Pollution

Abatement Capital Expenditures and Operating Cost.

U.S. Environmental Protection Agency (1986). "AP-42. Compilation of Air Pollutant Emission Factors. Supplement A, Stationary Point and Area Sources". Research Triangle Park, N.C. October.

Viscusi, A. Magat, Alan Carlin and Mark Dreyfus (1994). "Environmentally Responsibe

Energy Pricing", in Energy Journal, 15(2): 23-42.

Walter, Ingo, (1982). "Environmentally Induced Industrial Relocation to Developing Countries." In S. J. Rubin and T.R. Graham, eds., Environment and Trade, New Jersey: Allanheld, Ossun, and Co.

Wheeler, David and Paul Martin (1992). "Prices, Policies, and the International Diffusion of Clean

Technology: The Case of Wood Pulp Production". In:International Trade and the Environment, World

Bank Discussion Paper No 159, Patrick Low (Editor), The World Bank, Washington, D.C.

World Development Report (1992). "Development and the Environment". Oxford University Press, Inc. New York. 


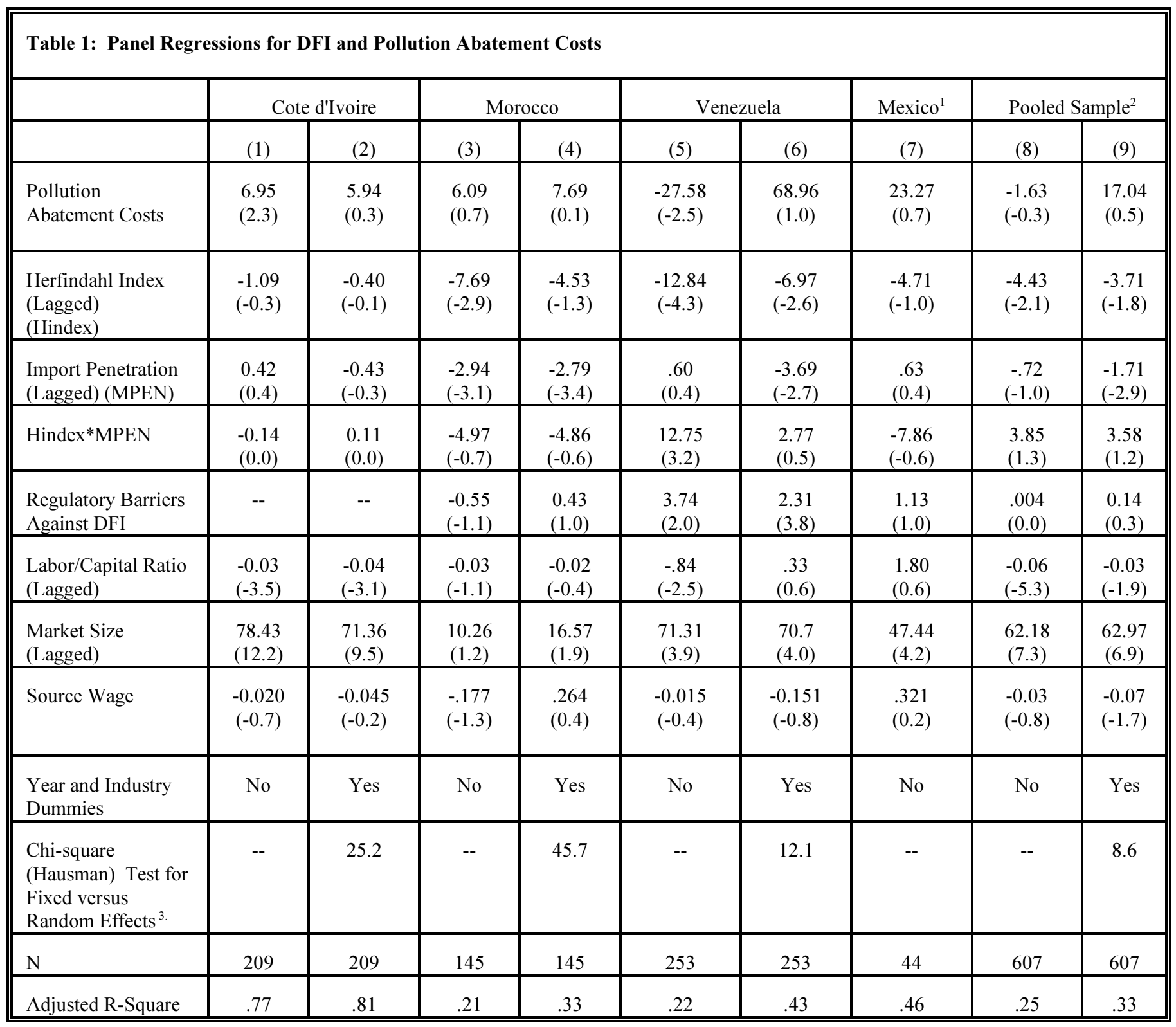

Note: T-statistics given in parenthesis. Dependent variable is the share of aggregate foreign investment in a given year assigned to each individual industry.

1. No lags; data on foreign investment only exists for 1990.

2. Includes country dummy variables. Excludes Mexico, which is a pure cross-section.

3. For a column (2), a value greater than 26 indicates rejection (at the 5 percent level) of the null hypothesis that fixed and random effect specifications are the same. For column (4), the critical value is 17 ; for column (6) the critical value is 20 , and for column (9), the critical value is 29. 
Table 2: Correlations Between Pollution Emission Intensities and Abatement Costs

\begin{tabular}{||l|c|c|c||}
\hline \hline BOD & $\begin{array}{c}\text { Suspended Particles } \\
\text { (SUSSPART) }\end{array}$ & $\begin{array}{c}\text { Biological Oxygen } \\
\text { Demand (BOD) }\end{array}$ & $\begin{array}{c}\text { Total Toxic Releases } \\
\text { (TOX) }\end{array}$ \\
\hline TOX & -0.08 & & \\
\hline $\begin{array}{l}\text { Pollution } \\
\text { Abatement } \\
\text { Costs }\end{array}$ & 0.03 & -0.10 & \\
\hline
\end{tabular}

Note: A " $"$ indicates statistical significance at the 5 percent level. 
Table 3: Cross-Section Time-Series Regressions for DFI with Alternative Specifications and Alternative Measures of Pollution Emissions (Coefficients on Pollution Abatement or Emissions Only)

\begin{tabular}{|c|c|c|c|c|c|c|c|c|c|}
\hline & \multicolumn{2}{|c|}{ Cote D'Ivoire } & \multicolumn{2}{|c|}{ Morocco } & \multicolumn{2}{|c|}{ Venezuela } & \multirow{2}{*}{$\begin{array}{c}\text { Mexico } \\
10.283 \\
(0.2)\end{array}$} & \multicolumn{2}{|c|}{ Pooled Sample } \\
\hline $\begin{array}{l}\text { Pollution } \\
\text { Abatement } \\
\text { Costs 1/ }\end{array}$ & $\begin{array}{l}6.95 \\
(1.1)\end{array}$ & $\begin{array}{l}5.94 \\
(0.2)\end{array}$ & $\begin{array}{l}6.09 \\
(0.4)\end{array}$ & $\begin{array}{l}7.69 \\
(0.2)\end{array}$ & $\begin{array}{c}-27.58 \\
(-1.3)\end{array}$ & $\begin{array}{c}68.96 \\
(1.1)\end{array}$ & & $\begin{array}{l}-1.63 \\
(-0.2)\end{array}$ & $\begin{array}{c}17.04 \\
(0.7)\end{array}$ \\
\hline $\begin{array}{l}\text { Pollution } \\
\text { Abatement } \\
\text { Costs 2/ }\end{array}$ & $\begin{array}{r}-0.23 \\
(0.0)\end{array}$ & $\begin{array}{l}-6.93 \\
(-0.8)\end{array}$ & $\begin{array}{l}8.88 \\
(0.7)\end{array}$ & $\begin{array}{l}2.07 \\
(0.1)\end{array}$ & $\begin{array}{l}-25.45 \\
(-1.3)\end{array}$ & $\begin{array}{c}52.16 \\
(0.9)\end{array}$ & -- & $\begin{array}{l}-0.97 \\
(-0.1)\end{array}$ & $\begin{array}{l}3.76 \\
(0.2)\end{array}$ \\
\hline $\begin{array}{l}\text { Pollution } \\
\text { Abatement } \\
\text { Costs 3/ } \\
\text { (GMM } \\
\text { Estimation) }\end{array}$ & $\begin{array}{l}3.99 \\
(1.0\end{array}$ & $\begin{array}{l}-22.13 \\
(-0.9)\end{array}$ & $\begin{array}{c}-12.98 \\
(-0.5)\end{array}$ & $\begin{array}{c}31.28 \\
(0.3)\end{array}$ & $\begin{array}{l}-6.84 \\
(-0.9)\end{array}$ & $\begin{array}{c}10.74 \\
(0.1)\end{array}$ & -- & $\begin{array}{l}1.60 \\
(0.4)\end{array}$ & $\begin{array}{c}-18.94 \\
(-0.7)\end{array}$ \\
\hline $\begin{array}{l}\text { SUSSPAR } \\
\mathrm{T}\end{array}$ & $\begin{array}{c}0.062 \\
(1.7)\end{array}$ & $\begin{array}{c}-5.569 \\
(-0.6)\end{array}$ & $\begin{array}{c}0.154 \\
(1.6)\end{array}$ & $\begin{array}{c}0.349 \\
(1.1)\end{array}$ & $\begin{array}{c}0.020 \\
(1.5)\end{array}$ & $\begin{array}{c}0.902 \\
(2.2)\end{array}$ & $\begin{array}{c}0.015 \\
(0.3)\end{array}$ & $\begin{array}{c}0.087 \\
(2.7)\end{array}$ & $\begin{array}{c}0.575 \\
(1.5)\end{array}$ \\
\hline BOD & $\begin{array}{c}-0.002 \\
(-3.6)\end{array}$ & $\begin{array}{c}0.011 \\
(0.1)\end{array}$ & $\begin{array}{c}0.001 \\
(1.2)\end{array}$ & $\begin{array}{c}-0.002 \\
(0.8)\end{array}$ & $\begin{array}{c}-0.003 \\
(-2.5)\end{array}$ & $\begin{array}{l}-0.001 \\
(-0.7)\end{array}$ & $\begin{array}{c}-0.004 \\
(-1.0)\end{array}$ & $\begin{array}{l}-0.002 \\
(-2.7)\end{array}$ & $\begin{array}{c}-0.001 \\
(-0.3)\end{array}$ \\
\hline TOX & $\begin{array}{c}0.010 \\
(2.1)\end{array}$ & $\begin{array}{c}0.012 \\
(0.8)\end{array}$ & $\begin{array}{c}-0.028 \\
(-2.0)\end{array}$ & $\begin{array}{c}-0.016 \\
(-1.1)\end{array}$ & $\begin{array}{c}-0.028 \\
(-2.0)\end{array}$ & $\begin{array}{c}0.006 \\
(0.6)\end{array}$ & $\begin{array}{l}0.025 \\
(0.4)\end{array}$ & $\begin{array}{l}-0.013 \\
(-1.8)\end{array}$ & $\begin{array}{c}0.007 \\
(0.6)\end{array}$ \\
\hline $\begin{array}{l}\text { Year and } \\
\text { Industry } \\
\text { Dummy }\end{array}$ & No & Yes & No & Yes & No & Yes & No & No & Yes \\
\hline
\end{tabular}

Notes: T-statistics in parenthesis. Dependent variable is the share of foreign investment in a particular ISIC category. See Table 1 for full specification. The specification above reproduces the specification in Table 1 , but either replaces pollution abatement costs with three different measures of pollution emissions or changes the basic specification.

1. Allows for group-wise heteroskedasticity.

2. Allows for first-order autocorrelation in the error term.

3. Estimation uses GMM estimation; only abatement costs, wages, and regulatory barriers against DFI are considered exogenous. Instruments for other variables include first lag and second lags of the exogenous variables and second lags of the endogenous variables. The only exception is Morocco (see text). 
Table 4: The Relationship Between Energy Intensity and Pollution Emissions Across Industries: Rank

Correlation Coefficients

\begin{tabular}{|c|c|c|c|c|c|c|c|c|c|c|}
\hline & Particulates & $\mathrm{BOD}$ & TOXLB & TOXUB & $\begin{array}{c}\text { Unskilled } \\
\text { Labor }\end{array}$ & $\begin{array}{c}\text { Skilled } \\
\text { Labor } \\
\end{array}$ & Capital & $\begin{array}{l}\text { Manufaactured } \\
\text { Inputs }\end{array}$ & $\begin{array}{c}\text { Raw } \\
\text { Material } \\
\text { Inputs }\end{array}$ & Energy \\
\hline Particulates & 1.00 & & & & & & & & & \\
\hline BOD & $0.29^{*}$ & 1.00 & & & & & & & & \\
\hline TOXLB & $0.27^{*}$ & $0.17^{*}$ & 1.00 & & & & & & & \\
\hline TOXUB & $0.30^{*}$ & $0.19^{*}$ & $0.73^{*}$ & 1.00 & & & & & & \\
\hline Unskilled Labor & $-0.15^{*}$ & $-0.16^{*}$ & $-0.16^{*}$ & $0.10^{*}$ & 1.00 & & & & & \\
\hline Skilled Labor & $-0.25^{*}$ & $-0.35^{*}$ & 0.01 & 0.05 & $0.36^{*}$ & 1.00 & & & & \\
\hline Capital & $0.28^{*}$ & 0.09 & $0.36^{*}$ & $0.38^{*}$ & 0.01 & $0.48^{*}$ & 1.00 & & & \\
\hline Manufactured Inputs & $-0.19^{*}$ & $-0.13^{*}$ & -0.00 & 0.06 & -0.01 & $-0.20^{*}$ & $-0.33^{*}$ & 1.00 & & \\
\hline Raw Material Inputs & $0.44^{*}$ & $0.34^{*}$ & $0.26^{*}$ & $0.17^{*}$ & $-0.33^{*}$ & $-0.42^{*}$ & 0.06 & $-0.24^{*}$ & 1.00 & \\
\hline Energy & $0.58^{*}$ & $0.22^{*}$ & $0.55^{*}$ & $0.52^{*}$ & 0.04 & 0.04 & $0.62^{*}$ & $-0.19^{*}$ & $0.34^{*}$ & 1.00 \\
\hline
\end{tabular}

A "*" indicates statistical significance at the 5 percent level. 
Table 5: Energy Intensity as a Determinant of Emission Intensity at the Plant Level, US Data

\begin{tabular}{|c|c|c|c|c|c|c|}
\hline & $\begin{array}{l}\text { All Plants } \\
\text { (1) }\end{array}$ & $\begin{array}{l}\text { All Plants } \\
\text { (2) }\end{array}$ & $\begin{array}{l}\text { Lumber and } \\
\text { Wood Products } \\
\text { (Except } \\
\text { Furniture) } \\
\text { (3) }\end{array}$ & $\begin{array}{l}\text { Chemicals and } \\
\text { Allied } \\
\text { Products } \\
\text { (4) }\end{array}$ & $\begin{array}{l}\text { Petroleum } \\
\text { Refining and } \\
\text { Related } \\
\text { Products } \\
\text { (5) }\end{array}$ & $\begin{array}{l}\text { Non-Electrical } \\
\text { Machinery (6) }\end{array}$ \\
\hline $\begin{array}{c}\text { Energy } \\
\text { Intensity }\end{array}$ & $\begin{array}{r}1880 \\
(29.4) \\
\end{array}$ & $\begin{array}{r}1859 \\
(29.0) \\
\end{array}$ & $\begin{array}{r}774 \\
(3.1) \\
\end{array}$ & $\begin{array}{c}2195 \\
(33.8) \\
\end{array}$ & $\begin{array}{l}1349 \\
(3.0) \\
\end{array}$ & $\begin{array}{l}3626 \\
(2.0) \\
\end{array}$ \\
\hline $\begin{array}{l}\text { Material } \\
\text { Inputs }\end{array}$ & $\begin{array}{c}72 \\
(2.5)\end{array}$ & -- & $\begin{array}{c}-2 \\
(-0.0)\end{array}$ & $\begin{array}{c}112 \\
(1.2)\end{array}$ & $\begin{array}{l}-72 \\
(1.0)\end{array}$ & $\begin{array}{c}45 \\
(0.3)\end{array}$ \\
\hline $\begin{array}{l}\text { SIC } \\
\text { Dummies }\end{array}$ & Yes & Yes & No & No & No & No \\
\hline $\mathrm{N}$ & 892 & 893 & 25 & 110 & 67 & 43 \\
\hline R-Square & .50 & .50 & .30 & .91 & .17 & .09 \\
\hline
\end{tabular}

Notes: T-statistics in parenthesis. All observations are by firm, for one year only. Columns (1) and (2) include all firms in 17 industries. Columns (3) through (6) are the four industries among 17 SIC industries for which a specification with energy and materials as independent variables yields a significant coefficient for energy. 
Table 6: Determinants of Energy Intensity in Selected Manufacturing Sectors:

Cote d'Ivoire, Mexico, and Venezuela

\begin{tabular}{|c|c|c|c|c|c|c|}
\hline & \multicolumn{2}{|c|}{ Côte d'Ivoire } & \multicolumn{2}{|c|}{ Mexico } & \multicolumn{2}{|c|}{ Venezuela } \\
\hline & (1) & (2) & (1) & (2) & (1) & (2) \\
\hline $\begin{array}{l}\text { Foreign } \\
\text { Ownership }\end{array}$ & $\begin{array}{l}-.0085 \\
(-2.0)\end{array}$ & $\begin{array}{l}.0900 \\
(3.1)\end{array}$ & $\begin{array}{l}-.0036 \\
(-2.3)\end{array}$ & $\begin{array}{c}0.0291 \\
(3.0)\end{array}$ & $\begin{array}{c}-0.0078 \\
(-3.7)\end{array}$ & $\begin{array}{c}0.0399 \\
(3.1)\end{array}$ \\
\hline $\begin{array}{l}\text { Public } \\
\text { Ownership }\end{array}$ & $\begin{array}{c}0.0013 \\
(.8)\end{array}$ & $\begin{array}{c}-0.1827 \\
(-2.4)\end{array}$ & - & - & - & - \\
\hline Age & $\begin{array}{l}0.0001 \\
(.8)\end{array}$ & $\begin{array}{l}.0027 \\
(2.9)\end{array}$ & - & - & $\begin{array}{c}-0.0001 \\
(-0.8)\end{array}$ & $\begin{array}{c}0.0006 \\
(2.2)\end{array}$ \\
\hline $\begin{array}{l}\text { Machinery } \\
\text { Imports }\end{array}$ & - & - & $\begin{array}{c}-0.0007 \\
(-0.8)\end{array}$ & $\begin{array}{c}0.0020 \\
(0.4)\end{array}$ & - & - \\
\hline $\mathrm{R}$ and $\mathrm{D}$ Intensity & - & - & $\begin{array}{c}-0.0340 \\
(-1.2)\end{array}$ & $\begin{array}{c}0.0885 \\
(0.5)\end{array}$ & $\begin{array}{c}0.0171 \\
(0.5)\end{array}$ & $\begin{array}{c}0.0429 \\
(0.2)\end{array}$ \\
\hline $\log ($ Electricity) & - & - & $\begin{array}{c}0.0107 \\
(19.2)\end{array}$ & $\begin{array}{c}0.0798 \\
(23.3)\end{array}$ & $\begin{array}{c}0.0088 \\
(6.3)\end{array}$ & $\begin{array}{l}.0643 \\
(25.3)\end{array}$ \\
\hline Log(Employees) & $\begin{array}{l}.006 \\
(3.5)\end{array}$ & $\begin{array}{l}-.058 \\
(-2.4)\end{array}$ & - & - & - & - \\
\hline $\begin{array}{l}\text { Log(Skilled } \\
\text { Workers) }\end{array}$ & - & - & $\begin{array}{l}-.0048 \\
(-5.5)\end{array}$ & $\begin{array}{l}-.0075 \\
(-1.4)\end{array}$ & $\begin{array}{c}-.0005 \\
(-0.8)\end{array}$ & $\begin{array}{l}.0043 \\
(1.6)\end{array}$ \\
\hline $\begin{array}{l}\text { Log(Unskilled } \\
\text { Workers) }\end{array}$ & - & - & $\begin{array}{l}.0027 \\
(2.6)\end{array}$ & $\begin{array}{l}-.0258 \\
(-4.1)\end{array}$ & $\begin{array}{c}-0.0012 \\
(-1.0)\end{array}$ & $\begin{array}{l}.0253 \\
(-7.0)\end{array}$ \\
\hline Log(Materials) & $\begin{array}{l}-.015 \\
(-9.4)\end{array}$ & $\begin{array}{l}0.016 \\
(1.6)\end{array}$ & $\begin{array}{l}-.0130 \\
(-17.6)\end{array}$ & $\begin{array}{l}-.035 \\
(-7.7)\end{array}$ & $\begin{array}{c}-.0103 \\
(-9.1)\end{array}$ & $\begin{array}{c}-.0071 \\
(-3.1)\end{array}$ \\
\hline $\begin{array}{l}\text { Log(Capital } \\
\text { Stock) }\end{array}$ & $\begin{array}{l}0.004 \\
(3.9)\end{array}$ & $\begin{array}{l}0.054 \\
(6.2)\end{array}$ & $\begin{array}{l}.0017 \\
(3.2)\end{array}$ & $\begin{array}{l}-.0003 \\
(-0.1)\end{array}$ & $\begin{array}{l}.0019 \\
(2.6)\end{array}$ & $\begin{array}{l}-0.0215 \\
(-11.6)\end{array}$ \\
\hline R-Square & 0.32 & .23 & 0.20 & 0.24 & 0.03 & .33 \\
\hline $\mathrm{N}$ & 929 & 929 & 4,661 & 4,651 & 14,147 & 14,022 \\
\hline
\end{tabular}

Notes:

In column (1), dependent variable is energy share in output

In column (2), the dependent variable is the electricity share in the plant's total energy use All models include sector dummy variables (4-digit SIC).

$\mathrm{T}$-values are given in parentheses. 
Table 7: The distribution of US Outbound Foreign Investment and Pollution Abatement Costs

\begin{tabular}{||l|c|c|c|c|c|c||}
\hline \multirow{4}{*}{} & \multicolumn{3}{|c|}{$\begin{array}{c}\text { Distribution of Foreign } \\
\text { Investment }\end{array}$} & \multicolumn{3}{c|}{$\begin{array}{c}\text { Distribution of Foreign } \\
\text { Investment } \\
\text { (STOCK) }\end{array}$} \\
\cline { 2 - 7 } & $(1)$ & $(2)$ & $(3)$ & $(4)$ & $(5)$ & $(6)$ \\
\hline Pollution Abatement Costs & $\begin{array}{c}0.224 \\
(2.0)\end{array}$ & $\begin{array}{c}0.108 \\
(0.9)\end{array}$ & $\begin{array}{c}-1.086 \\
(-2.3)\end{array}$ & $\begin{array}{c}0.450 \\
(2.9)\end{array}$ & $\begin{array}{c}0.296 \\
(1.8)\end{array}$ & $\begin{array}{c}0.012 \\
(0.2)\end{array}$ \\
\hline $\begin{array}{l}\text { Import Penetration } \\
\text { (Lagged) }\end{array}$ & - & $\begin{array}{c}-0.009 \\
(-0.5)\end{array}$ & $\begin{array}{c}0.008 \\
(0.2)\end{array}$ & - & $\begin{array}{c}0.014 \\
(1.0)\end{array}$ & $\begin{array}{c}-0.017 \\
(-1.2)\end{array}$ \\
\hline Export Share (Lagged) & - & $\begin{array}{c}-0.014 \\
(-0.6)\end{array}$ & $\begin{array}{c}0.010 \\
(0.1)\end{array}$ & - & $\begin{array}{c}0.047 \\
(2.2)\end{array}$ & $\begin{array}{c}0.008 \\
(0.4)\end{array}$ \\
\hline Labor/Capital Ratio \\
(Lagged)
\end{tabular}

Notes: All specifications corrected for arbitrary heteroskedasticity. T-statistics in parenthesis. 